\title{
В МОСКОВСКОМ ГУМАНИТАРНОМ УНИВЕРСИТЕТЕ СОЗДАН ШЕКСПИРОВСКИЙ ЦЕНТР
}

\author{
Н. В. Захаров, Б. Н. Гайдин \\ Московский гуманитарный университет
}

Аннотация: $\quad$ с статье представляется новый научноисследовательский Центр, созданный в Московском гуманитарном университете, в составе Института фундаментальных и прикладных исследований - Шекспировский центр. Дается предыстория, презентуются достижения, объясняются цели нового центра.

Ключевые слова: Московский гуманитарный университет; Шекспир; Шекспировский центр; шекспироведение

\section{A SHAKESPEAREAN CENTRE IS ESTABLISHED AT MOSCOW UNIVERSITY FOR THE HUMANITIES}

\author{
N. V. Zakharov, B. N. Gaidin \\ Moscow University for the Humanities
}

Abstract: The paper presents the new scientific research Centre established at Moscow University for the Humanities within the Institute of Fundamental and Applied Studies - the Shakespearean Centre. The authors give the background, present the achievements, and explain the objectives of the new centre.

Keywords: Moscow University for the Humanities; Shakespeare; Shakespearean Centre; Shakespearean studies

2 октября 2017 г. приказом ректора И. М. Ильинского Центр теории и истории культуры Института фундаментальных и прикладных исследований МосГУ (ИФПИ МосГУ) был преобразован в Шекспировский центр, который возглавил доктор философии (PhD), кандидат филологических наук, ученый секретарь Шекспировской комиссии РАН Н. В. Захаров.

Изучение наследия Уильяма Шекспира, в том числе его восприятия в отечественной и зарубежной культуре представляет собой особое направление в научной деятельности ИФПИ МосГУ. С 2004 года в стенах ИФПИ продолжает работу постоянно действующий семинар «Шекспировские штудии». На данный момент проведено 21 заседание, выпущено в свет 18 сборников материалов.

У истоков возникновения шекспировской научной школы МосГУ стоял выдающийся отечественный ученый, литературовед и культуролог, 
доктор филологических наук, профессор, заслуженный деятель науки РФ, академик Международной академии наук (IAS), лауреат Бунинской премии Владимир Андреевич Луков (1948-2014). В целом ряде своих фундаментальных работ он показал, как выстраиваются литературные концентры русской литературы, среди которых одним из важнейших является Шекспир. В известной мере к этой группе исследований следует отнести и многочисленные работы Вл. А. Лукова о Шекспире, большинство из которых были написаны в период его работы в МосГУ. Эти исследования не только о Шекспире и его творчестве, но и о таких культурных феноменах, как «культ Шекспира», «шекспиризация», «шекспиризм», «шекспиросфера» и т. д.

Обращение к шекспировской теме Вл. А. Луковым не случайно, этому способствовал его интерес к творчеству великого драматурга со школьных лет. В 2004 году Вл. А. Луков встретился в МосГУ с шекспироведом и пушкинистом Н. В. Захаровым. Этот союз объединил шекспироведение и тезаурусный подход. Многие работы по шекспировской тематике Вл. А. Луков и Н. В. Захаров написали вместе. Они инициировали издание сборников «Шекспировские штудии», постепенно в МосГУ сложилось сообщество шекспироведов - Б. Н. Гайдин, И. И. Лисович, В. С. Макаров, В. Р. Поплавский и др. Кроме того, значительная часть работы Шекспировской комиссии РАН стала проводиться на базе ИФПИ, благодаря чему МосГУ как шекспировский центр заслужил признание в нашей стране и за рубежом.

Шекспировские труды Вл. А. Лукова и его соавторов продвинули вперед и тезаурусную методологию по целому ряду пунктов. Здесь можно обозначить появление в книге Н. В. Захарова и Вл. А. Лукова «Гений на века» новой идеи тезаурусного расширения. Шекспировские работы Вл. А. Лукова могут быть также рассмотрены применительно к литературному творчеству в контексте выдвинутой им теории персональных моделей. Шекспировские штудии Вл. А. Лукова с применением тезаурусного подхода были продолжены в монографиях Н. В. Захарова и Б. Н. Гайдина: Захаров Н. В. Шекспиризм русской классической литературы : тезаурусный анализ / отв. ред. Вл. А. Луков ; Моск. гуманит. ун-т. Ин-т фундамент. и прикл. исследований ; МАН (IAS). М. : Изд-во Моск. гуманит. ун-та, 2008. 320 с.; Гайдин Б. Н. Вечные образы как константы культуры: тезаурусный анализ «гамлетовского вопроса». Saarbrücken : Lambert Academic Publishing, 2011.212 с.; и др.

За последние 10 лет 16 «шекспировских проектов» МосГУ были поддержаны грантами РГНФ, РФФИ и Совета по грантам Президента РФ. Были проведены 6 крупных Международных научных конференций «Шекспировские чтения» с участием западных шекспирологов из Великобритании, Италии, Нидерландов, Польши, США, Тайваня, Чехии, Франции и 
ЮАР (2006, 2008, 2010, 2012, 2014, 2016).

Издаются сборники статей. В 2011 году в издательстве «Наука» вышел том «Шекспировские чтения 2006», а в 2010 г. в издательстве Московского гуманитарного университета - «Шекспировские чтения 2008/2010». В настоящее время готовятся к изданию сборники статей «Шекспировские чтения 2012/2014» и «Шекспировские чтения 2016».

Шекспироведы МосГУ публикуют свои научные труды на иностранных языках (английском, финском и др.). Например, в 2014 г. в «Глобальном шекспировском журнале» вышла статья Н. В. Захарова Hamlet on the Post-Soviet Stage (Global Shakespeare Journal, vol. I, issue 2 / March 2014. P. 179-192). В начале 2016 г. были опубликованы печатная и цифровая версии «Кембриджской всемирной шекспировской энциклопедии» (The Cambridge World Shakespeare Encyclopedia). В составе авторского коллектива Россию представили заместитель председателя Шекспировской комиссии при Научном совете «История мировой культуры» РАН, доктор филологических наук, профессор И. С. Приходько (1943-2014) и Н. В. Захаров. Они подготовили статьи о русской рецепции «Отелло» и «Гамлета» для раздела «Знаковые персонажи» (“Iconic Characters”), редактором которого была профессор из Бразилии Аймара Резенде (Aimara Resende, Федеральный университет Минас-Жерайс).

Сотрудники ИФПИ, занимающиеся изучением творчества Шекспира и его влияния на мировую культуру, ежегодно участвуют в международных научных конференциях в России и за ее пределами: в Международной шекспировской конференции в Стратфорде-на-Эйвоне (Великобритания, 2010, 2014, 2016), ежегодной международной конференции Шекспировской ассоциации Америки $(2009,2010,2014,2016)$, Всемирных шекспировских конгрессах (Прага, 2012; Лондон - Стратфорд-на-Эйвоне, 2016), Международной научной конференция «Шекспир в лохмотьях: сопоставление его произведений в кино и на телевидении» (Феррара, Италия, 2013), VIII конференции Европейской шекспировской исследовательской ассоциации «Европа Шекспира: Шекспир(ы) Европы)» в Вустере (Великобритания, 2015), IX конференции «Шекспир и европейские театральные культуры: (ан)атомизация текста и сцены» в Гданьске (Польша, 2017) и др.

Созданный Шекспировский центр позволит продолжить и интенсифицировать научные исследования, которые носят междисциплинарный и транснациональный характер. Шекспировская комиссия РАН и Шекспировский центр ИФПИ МосГУ объединяют крупнейших российских шекспироведов - специалистов в области истории театра, сравнительного литературоведения, искусствознания, культурологии и других отраслей гуманитарного знания, организуют и проводят регулярные заседания Шекспировской комиссии РАН (2003-2017). В 2015 г. при поддержке 
РГНФ была проведена Международная междисциплинарная научнопрактическая конференция «Роль факта и воображения в конструировании художественных и виртуальных миров шекспировской Англии», а также состоялись 7 заседаний Международного научного семинара «Шекспир в междисциплинарных гуманитарных исследованиях», по итогам которого была издана монография: Шекспир в междисциплинарных гуманитарных исследованиях: коллективная монография по материалам Международного научного семинара / ред.-сост. В. С. Макаров, Н. В. Захаров, Б. Н. Гайдин. М. : Изд-во Моск. гуманит. ун-та, 2015. 238 с.

Шекспировский центр планирует продолжать вести активную просветительскую работу среди молодежи, студенчества и всех поклонников творчества английского драматурга, выступать с открытыми лекциями в МосГУ, лицеях и школах Москвы, проводить конкурсы переводов шекспировских пьес и сонетов, конкурсы на знание творчества Шекспира и т. д. В настоящее время ведется работа по организации Школьного шекспировского фестиваля в Москве и Санкт-Петербурге.

Исходя из современных тенденций в гуманитарном знании, Шекспировский центр ИФПИ продолжает работу по развитие новых информационных технологий в области шекспироведения и обучения предметам общегуманитарного цикла. С 2004 г. был реализован ряд интернет-проектов, напрямую или косвенно связанных с изучением наследия Шекспира. За эти годы сотрудникам ИФПИ МосГУ удалось создать шекспировский научно-образовательный сегмент в русскоязычном Интернете. Ведется работа по развитию электронного образования, изучению опыта создания массовых открытых онлайн-курсов (МOOK), перспектив их создания и использования в МосГУ.

Начиная с 2005 г. в работе над интернет-проектами МосГУ принимают участие студенты и аспиранты университета. Их помощь помогла создать три шекспировских сайта в русскоязычном сегменте Интернета:

Информационно-исследовательская база данных «Русский Шекспир» (руководитель проекта Н. В. Захаров; www.rus-shake.ru) включает в себя публикацию переводов произведений Шекспира на русский язык, вольных переложений и переделок его произведений, публикацию критических работ и исследований по общим вопросам творчества Шекспира, по проблеме авторства, истории шекспироведения, по отдельным произведениям великого драматурга, их театральным и кинематографическим версиям. База данных содержит как оригинальные результаты текстологических исследований авторского коллектива, так и оцифрованные печатные источники, многие из которых ранее были недоступны большинству исследователей.

«Мир Шекспира: Электронная энциклопедия» (под ред. Н. В. Захарова, 
Б. Н. Гайдина; www.world-shake.ru). В проекте решаются задачи теоретического осмысления проблем освоения творчества зарубежного писателя русской культурой: собираются, анализируются и обобщаются материалы о рецепции наследия Шекспира в процессе диалога культур России и других стран: сведения о переводах, изданиях, постановках на сцене, кино- и телеэкранизациях, шекспировских образах и сюжетах в живописи, музыке, балете, литературная, театральная, искусствоведческая критика, исследования, интерпретации, описания и ссылки на различные шекспировские интернет-ресурсы, примеры интерпретаций Шекспира в повседневной культуре и т. д.

Информационно-исследовательская база данных «Современники Шекспира: электронное научное издание» (руководитель Н. В. Захаров; www.around-shake.ru). Цель проекта - собрать и обобщить известные на сегодняшний день сведения о месте современников Шекспира в культурах России, Великобритании, США и других стран, разместить в открытом доступе русскоязычные переводы произведений современников английского драматурга, научные исследования об интерпретациях их творчества в театре, кино и на телевидении, сведения о рецепции образов и сюжетов их произведений в живописи, музыке и других видах искусства. Коллектив проекта осуществляет мониторинг электронных библиотек, исследовательских интернет-ресурсов и других проектов, посвященных современникам Шекспира. Многие тексты представлены на русском языке впервые, ведется работа по оцифровке редких и малодоступных изданий.

В настоящее время Шекспировский центр совместно с Научноисследовательским отделом цифровых технологий ИФПИ работает над проектом «Разработка и внедрение в открытом доступе онлайнпрограммы сравнительного тезаурусного анализа русских переводов произведений У. Шекспира», поддержанном грантом РФФИ (№ 17-0412038в). Корпус русскоязычных переводов произведений поэта и драматурга будет представлен на платформе, разработанной участниками проекта, с возможностью визуализированного лингвистического анализа переводов и сравнения их между собой. Демоверсия корпуса доступна по адресу: http://shakespearecorpus.ru/.

Дата поступления: 15.10.2017 2.

Захаров Николай Владимирович - доктор философии (Ph.D.) кандидат филологических наук, директор Шекспировского центра Института фундаментальных и прикладных исследований Московского гуманитарного университета. Адрес: 111395, Россия, г. Москва, ул. Юности, д. 5, корп. 6, каб. 17. Тел.: +7 (499) 374-59-30. Эл. адрес: nzakharov@mosgu.ru 
Гайдин Борис Николаевич - кандидат философских наук, начальник отдела цифровых технологий Института фундаментальных и прикладных исследований Московского гуманитарного университета. Адрес: 111395, Россия, г. Москва, ул. Юности, д. 5, корп. 6, каб. 17. Тел.: +7 (499) 374-59-30. Эл. адрес: bngaydin@mosgu.ru

Zakharov Nikolay Vladimirovich, Doctor of Philosophy, Candidate of Philology, Director, Shakespearean Centre, Institute of Fundamental and Applied Studies, Moscow University for the Humanities. Postal address: 5, Bld. 6, Yunosti St., Moscow, Russian Federation 111395. Tel.: +7 (499) 374-59-30. E-mail:nzakharov@mosgu.ru

Gaidin Boris Nikolayevich, Candidate of Philosophy, Director, Department of Digital Technologies, Institute of Fundamental and Applied Studies, Moscow University for the Humanities. Postal address: 5, Bld. 6, Yunosti St., Moscow, Russian Federation 111395. Tel.: +7 (499) 374-59-30. E-mail: bngaydin@ mosgu.ru

\section{Для циитирования:}

Захаров Н. В., Гайдин Б. Н. В Московском гуманитарном университете создан Шекспировский центр [Электронный ресурс] // Научные труды Московского гуманитарного университета. 2017. № 5. URL: http://journals. mosgu.ru/trudy/article/view/570 DOI: 10.17805/trudy.2017.5.8 (дата обращения: дд.мм.гг.). 